\title{
Nitrogen and mepiquat chloride can affect fiber quality and cotton yield
}

\author{
Aguinaldo J. F. Leal ${ }^{1}$, Gabriel L. Piati², Rafael C. Leite ${ }^{3}$, Mayara S. Zanella ${ }^{4}$, \\ Christian R. W. S. Osorio ${ }^{3}$ \& Sebastião F. Lima ${ }^{3}$
}

\begin{abstract}
${ }^{1}$ Universidade Federal do Triângulo Mineiro/Faculdade de Agronomia, Iturama, MG, Brasil. E-mail: aguinaldo@iturama.uftm.edu.br - ORCID: 0000-0003-4815-5055

${ }^{2}$ Universidade Federal da Grande Dourados/Faculdade de Ciências Agrárias, Dourados, MS, Brasil. E-mail: gabrielpiati@hotmail.com - ORCID: 0000-0001-9059-505X

${ }^{3}$ Universidade Federal de Mato Grosso do Sul/Faculdade de Agronomia, Chapadão do Sul, MS, Brasil. E-mail: rafaeldacostaleite@hotmail.com ORCID: 0000-0002-5902-183X; c.osorio@hotmail.com - ORCID: 0000-0002-0431-3149; sebastiao.lima@ufms.br (Corresponding author) - ORCID: 0000-0001-5693-912X

${ }^{4}$ Universidade Federal de Mato Grosso do Sul/Faculdade de Ciências Farmacêuticas, Alimentos e Nutrição, Campo Grande, MS, Brasil. E-mail: may_tate@hotmail.com - ORCID: 0000-0002-0108-1768
\end{abstract}

\begin{abstract}
The use of mepiquat chloride (MC) in cotton (Gossypium hirsutum L.) cultivation has increased significantly in recent years. The use of MC, a growth regulator, results in higher precocity and lower height and consequently increases yield and reduces crop costs. The objective of this study was to evaluate the effects of nitrogen (N) and MC doses on fiber quality and cotton yield. This study was conducted during the 2012/13 and 2013/14 harvests in the experimental area of the Fundação de Apoio à Pesquisa Agropecuária de Chapadão, located in the municipality of Chapadão do Sul, MS, Brazil, at $18^{\circ} 48^{\prime} 45.9^{\prime \prime} \mathrm{S}, 52^{\circ} 36^{\prime} 3^{\prime \prime} \mathrm{W}$, having an altitude of $820 \mathrm{~m}$. The experimental design was a randomized blocks in a $5 \times 4$ factorial scheme comprised of five $\mathrm{N}$ doses $\left(0,40,80,120,160 \mathrm{~kg} \mathrm{ha}^{-1}\right)$ and four MC doses $\left(0,50,100,150 \mathrm{~mL} \mathrm{ha}^{-1}\right)$ with four repetitions. Analyses of fiber quality included: length, uniformity, elongation, strength, micronaire index, reflectance, yellowing degrees and short fiber content. Regarding cotton yield, green color index (GCI), plant height at harvest time, and cotton seed yield were determined. The best results for fiber quality and productivity occurr with the application of $76.8 \mathrm{~mL} \mathrm{ha}^{-1}$ of $\mathrm{MC}$ to the cotton crops when the $\mathrm{N}$ dose is greater than $80 \mathrm{~kg} \mathrm{ha}^{-1}$. Increasing $\mathrm{N}$ doses causes an increase in cotton yield and micronaire index, but there is a decrease in fiber uniformity.
\end{abstract}

Key words: Gossypium hirsutum, growth regulator, cotton fertilization

\section{Nitrogênio e cloreto de mepiquat podem afetar qualidade de fibra e produtividade do algodoeiro}

RESUMO: O uso do cloreto de mepiquat (CM) no cultivo de algodão (Gossypium hirsutum L.) aumentou significativamente nos últimos anos. O uso do CM, um regulador de crescimento, resulta em maior precocidade e menor altura e, consequentemente, aumento da produtividade e redução dos custos da cultura. O objetivo deste estudo foi avaliar os efeitos de doses de nitrogênio e CM sobre a qualidade da fibra e produtividade do algodoeiro. O estudo foi conduzido nas safras 2012/13 e 2013/14, na área experimental da Fundação de Apoio à Pesquisa Agropecuária de Chapadão, em Chapadão do Sul, MS, a $18^{\circ} 48^{\prime}$ 45,9” S, 52³6' 3" W, com altitude de $820 \mathrm{~m}$. O delineamento experimental foi em blocos casualizados em esquema fatorial $5 \times 4$, correspondendo a cinco doses de $\mathrm{N}\left(0,40,80,120,160 \mathrm{~kg} \mathrm{ha}^{-1}\right)$ e quatro doses de CM $\left(0,50,100,150 \mathrm{~mL} \mathrm{ha}^{-1}\right)$ com quatro repetições. As avaliações realizadas para análises da qualidade da fibra foram: comprimento, uniformidade, elongação, resistência, índice micronaire, reflectância, graus de amarelecimento e conteúdo de fibras curtas. Para a produtividade do algodão foram feitas análises de índice de cor verde (ICV), altura de plantas no momento da colheita e produtividade do algodão em caroço. Os melhores resultados em qualidade de fibras e produtividade ocorrem com a aplicação de $76,8 \mathrm{~mL} \mathrm{ha}^{-1}$ de CM no algodoeiro quando a dose de $\mathrm{N}$ é maior que $80 \mathrm{~kg} \mathrm{ha}^{-1}$. Doses crescentes de $\mathrm{N}$ causam aumento na produtividade de algodão e no índice micronaire, porém há uma diminuição na uniformidade de fibras.

Palavras-chave: Gossypium hirsutum, regulador de crescimento, adubação do algodoeiro 


\section{INTRODUCTION}

The Brazilian cotton (Gossypium hirsutum L.) industry is based on a production system with large areas and soils with low natural fertility; thus, requiring correction and frequent fertilization (Silva \& Almeida, 1998). The world production of cotton during the 2016/17 harvest was 23.09 million tons of cotton lint, with Brazil being the fifth largest cotton producer in the world, contributing 6.3\% to the world total (CONAB, 2018).

The most limiting nutrient for the production of cotton is nitrogen $(\mathrm{N})$. It is the most absorbed mineral from the soil by this crop and directly influences crop height, fruiting, yield and fiber quality (Ma et al., 2008; Ducamp et al., 2012).

High $\mathrm{N}$ concentrations increase the production of vegetative organs, reducing the efficiency of its use and negatively affecting the quality of the produced fiber, as well as generating higher production costs (Ma et al., 2008; Zhou \&Yin, 2014). Mepiquat chloride (MC) (1,1-dimethylpiperidinium) is currently one of the most widely used growth regulators and increases the synthesis and degradation of gibberellic acids (Wang et al., 2014).

Growth regulator application in cotton crops causes reduced light interception by the crop, changes the canopy structure, and increases the plant's efficiency by converting the intercepted radiation into dry matter, increasing the translocation of photoassimilates to the reproductive parts in detriment to the vegetative area (Gonias et al., 2012). However, it can also promote an increase in the number and mass of cotton buds, in addition to increasing the resistance and length of the fibers (Ren et al., 2013; Gu et al., 2014).

Therefore, the objective of this study was to evaluate the effects of $\mathrm{N}$ and $\mathrm{MC}$ doses on cotton fiber quality and yield.

\section{Material ANd Methods}

This study was conducted during the 2012/13 and 2013/14 harvests, in the experimental area of the Fundação de Apoio à Pesquisa Agropecuária de Chapadão, located in the municipality of Chapadão do Sul, MS, Brazil, at $18^{\circ} 48^{\prime} 45.9^{\prime \prime}$ S, $52^{\circ} 36^{\prime} 3^{\prime \prime}$ W, having an altitude of $820 \mathrm{~m}$. The climate of the region is classified as tropical humid, with dry winters and rainy summers (Cunha et al., 2013). Rainfall and air temperature data were recorded during the experiments (Figure 1).
This study was conducted under a no-tillage system. The cotton crop was sowed during December 2012 with an FMX 993 cultivar and during December 2013 with a DP 555 BG RR cultivar. Both harvests were completed after a total cycle of 180 days. Fiber quality was evaluated only for the 2012/13 harvest. Soil fertilization for both harvests was $426 \mathrm{~kg} \mathrm{ha}^{-1}$ starting from 06-24-14 + 4.9\% S. Topdressing fertilization for both harvests was performed using $100 \mathrm{~kg} \mathrm{ha}^{-1}$ of $\mathrm{KCl}$ at 35 days after sowing.

The experimental design was a randomized blocks in a $5 \times 4$ factorial scheme, with five $\mathrm{N}$ doses $(0,40,80,120$, $\left.160 \mathrm{~kg} \mathrm{ha}^{-1}\right)$ using urea (45-00-00) and four MC doses (0, 50, $100,150 \mathrm{~mL} \mathrm{ha}^{-1}$ ) with four repetitions. Each experimental plot consisted of four planting lines that were $5.5 \mathrm{~m}$ in length and spaced $0.9 \mathrm{~m}$. The $\mathrm{N}$ treatments were applied in topdressing, with an application at two times $(1 / 2+1 / 2)$ during the $\mathrm{V} 5$ and B6 phenological stages. The MC was applied in three treatments $(1 / 3+1 / 3+1 / 3)$ during the B6, F2 and $\mathrm{C} 1$ phenological stages; these applications occurred when the first upper internode exceeded $5 \mathrm{~cm}$.

The soil in the experimental area was classified as Oxisol with a clayey texture. Its chemical characteristics in 2013 included $14.3 \mathrm{mg} \mathrm{dm}^{-3} \mathrm{P}$ (res); $27.9 \mathrm{~g} \mathrm{dm}^{-3}$ organic matter; 5.1 $\mathrm{pH}\left(\mathrm{CaCl}_{2}\right) ; \mathrm{K}, \mathrm{Ca}, \mathrm{Mg}, \mathrm{H}+\mathrm{Al}=0.2,2.8,0.6$, and $2.7\left(\mathrm{cmol}_{\mathrm{c}} \mathrm{dm}^{-3}\right)$, respectively; $6.27 \mathrm{cmol}_{c} \mathrm{dm}^{-3}$ cation exchange capacity, and $56.9 \%$ base saturation. The chemical characteristics in 2014 were $19.3 \mathrm{mg} \mathrm{dm}^{-3} \mathrm{P}$ (res); $25.9 \mathrm{~g} \mathrm{dm}^{-3}$ organic matter; $5.3 \mathrm{pH}$ $\left(\mathrm{CaCl}_{2}\right) ; \mathrm{K}, \mathrm{Ca}, \mathrm{Mg}, \mathrm{H}+\mathrm{Al}=0.3,2.9,0.7$ and $2.2\left(\mathrm{cmol}_{\mathrm{c}} \mathrm{dm}^{-3}\right)$, respectively; $5.27 \mathrm{cmol} \mathrm{dm}_{c}^{-3}$ cation exchange capacity, and $59.1 \%$ base saturation.

The evaluations performed during 2012/13 were plant height at the time of harvest, green color index (GCI) (using an electronic chlorophyllometer) when the crop reached the F4 stage, cotton seed yield and weight 10-bud, and evaluations linked to fiber quality, including length, uniformity, elongation, strength, micronaire index, reflectance, yellowing degrees maturity, and short fiber content. The evaluations were conducted using the High Volume Instrument (Sestren \& Lima, 2007). During the 2013/14 crop season, the mean 10-bud mass and cotton seed yield were determined.

The data were submitted to analysis of variance and regression analysis method was used for significant results with $\mathrm{p} \leq 0.5$ according to the $\mathrm{F}$ test.

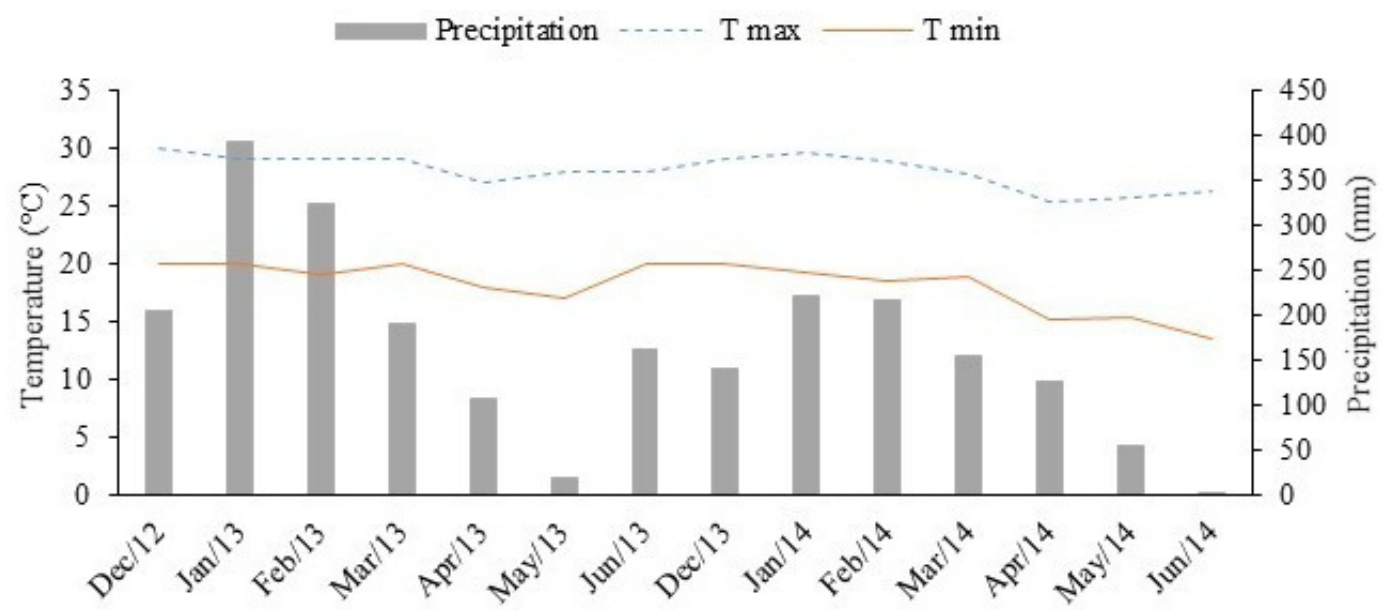

Figure 1. Mean temperature and precipitation for the agricultural years 2012/13 and 2013/14. Chapadão do Sul, 2014 


\section{Results AND Discussion}

During the 2012/13 harvest, an isolated effect of the factors MC and N was observed for the GCI (Table 1) and uniformity of distribution (UD) (Table 2). Further, an isolated effect of $\mathrm{MC}$ on the height and an interaction between $\mathrm{MC}$ and $\mathrm{N}$ for the yield were revealed (Table 1). During the 2013/14 harvest, an isolated effect of MC and $\mathrm{N}$ was observed for yield and MC effected the weight 10-bud (Table 2).

MC application increased the GCI (Figure 2A), and the same effect was observed for the $\mathrm{N}$ doses (Figure 2B).

Increasing the $\mathrm{N}$ supply to the plant directly affects chlorophyll production, causing it to increase because of its structural performance in this molecule (Wiedenfeld et al., 2009); thus, increasing the $\mathrm{N}$ supply increases the chlorophyll rate and the GCI (Figure 2B). However, MC could alter leaf morphology and physiology, increasing the photosynthetic rate, which is indirectly reflected as an increased chlorophyll rate; consequently, increasing the GCI (Figure 2A).

Increasing the $\mathrm{MC}$ doses decreased plant height by up to $23 \%$ in relation to the zero dose (Figure 3).

A decrease in cotton plant height occurred in relation to MC dose (Figure 3), as this directly affected the length and diameter of the internodes, as well as reducing the leaf area $(\mathrm{Gu}$

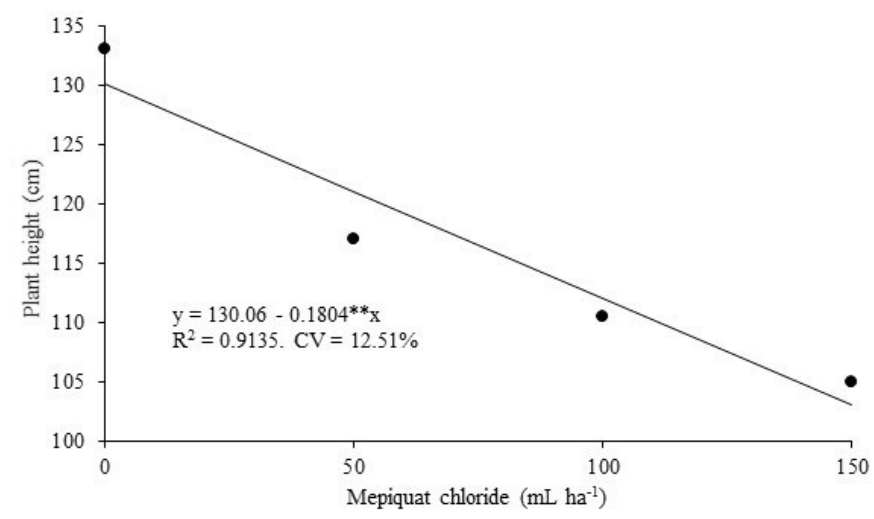

** Significant at $\mathrm{p} \leq 0.01$ according to the F test

Figure 3. Effect of mepiquat chloride (MC) doses on the height of cotton crops during the 2012/13 harvest

et al., 2014). This was caused by a reduction in GA levels, $\mathrm{GA}_{3}$ and $\mathrm{GA}_{4}$, because $\mathrm{MC}$ inhibits $\mathrm{GA}$ producing enzymes, causing cells to be less longitudinally and transversally developed (Wang et al., 2012).

The bud mass was only altered by MC doses for the 2013/14 crop, with an increase of $11 \%$ for the $87 \mathrm{~mL} \mathrm{ha}^{-1}$ dose in relation to the control; however, larger doses resulted in a decrease in the 10-bud mass values (Figure 4A).

Table 1. Effects of mepiquat chloride (MC) and nitrogen (N) on cotton yield and yield characteristics: Green color index (GCI), plant height, yield and weight 10-bud during the 2012/13 and 2013/14 harvests

\begin{tabular}{|c|c|c|c|c|c|c|}
\hline Harvest & Variables & DF & GCI & $\begin{array}{l}\text { Height } \\
\text { (cm) }\end{array}$ & $\begin{array}{c}\text { Yield } \\
\left(\mathrm{kg} \mathrm{ha}^{-1}\right)\end{array}$ & $\begin{array}{l}\text { Weight 10-bud } \\
\text { (g) }\end{array}$ \\
\hline \multirow{3}{*}{$2012 / 2013$} & $\mathrm{~N}$ & 4 & $24,158^{\star \star}$ & $1,299^{\text {ns }}$ & $1,022^{\mathrm{ns}}$ & $2,067^{\text {ns }}$ \\
\hline & MC & 3 & $162,40^{\star *}$ & $13,97^{\star \star}$ & $0,283^{\text {ns }}$ & $0,488^{\text {ns }}$ \\
\hline & $\mathrm{N} \times \mathrm{MC}$ & 12 & $0,686^{\text {ns }}$ & $0,591^{\mathrm{ns}}$ & $1,872^{\star *}$ & $1,584^{\text {ns }}$ \\
\hline \multirow{3}{*}{$2013 / 2014$} & N & 4 & ---- & ----- & $7,446^{* \star}$ & $0,599^{\text {ns }}$ \\
\hline & MC & 3 & ---- & ---- & $3,880^{\star *}$ & $5,296^{* *}$ \\
\hline & $\mathrm{N} \times \mathrm{MC}$ & 12 & ----- & --.-- & $0,230^{\text {ns }}$ & $0,772^{\text {ns }}$ \\
\hline
\end{tabular}

*,** and ${ }^{\mathrm{ns}}$ - Significant at $\mathrm{p} \leq 0.05, \mathrm{p} \leq 0.01$ and not significant according to the $\mathrm{F}$ test, respectively; DF - Degrees of freedom

Table 2. Effects of mepiquat chloride (MC) and nitrogen $(\mathrm{N})$ on the quality of cotton fiber: length (Len), uniformity of distribution (UD), strength (Str), elongation (Elo), micronaire (Mic), degrees of reflection (DR), yellow degrees (YD), maturity (Mat) and short fiber content (SFC) during the 2012/13 harvest

\begin{tabular}{|c|c|c|c|c|c|c|c|c|c|}
\hline $2012 / 2013$ & $\begin{array}{l}\text { Len } \\
(\mathrm{mm})\end{array}$ & $\begin{array}{l}\text { UD } \\
(\%)\end{array}$ & $\begin{array}{c}\text { Str } \\
\left.(\mathrm{CN} \mathrm{tex})^{-1}\right)\end{array}$ & $\begin{array}{l}\text { Elo } \\
(\%)\end{array}$ & $\begin{array}{c}\text { Mic } \\
\left(\mu \mathrm{g} \mathrm{in}^{-2}\right)\end{array}$ & $\begin{array}{l}\text { DR } \\
(\%)\end{array}$ & $\begin{array}{c}\text { YD } \\
(+b)\end{array}$ & Mat & $\begin{array}{l}\text { SFC } \\
(\%)\end{array}$ \\
\hline $\mathrm{N}$ & $0,48^{\text {ns }}$ & $3,369^{*}$ & $0,14^{\mathrm{ns}}$ & $0,747^{\mathrm{ns}}$ & $0,737^{\mathrm{ns}}$ & $0,074^{\text {ns }}$ & $2,134^{\mathrm{ns}}$ & $1,261^{\text {ns }}$ & $2,13^{\text {ns }}$ \\
\hline MC & $1,26^{\text {ns }}$ & $4,089^{*}$ & $1,757^{\mathrm{ns}}$ & $0,67^{\mathrm{ns}}$ & $2,74^{\mathrm{ns}}$ & $0,674^{\text {ns }}$ & $2,286^{\mathrm{ns}}$ & $0,583^{\text {ns }}$ & $2,38^{\text {ns }}$ \\
\hline $\mathrm{N} \times \mathrm{MC}$ & $1,8^{\text {ns }}$ & $0,877^{\mathrm{ns}}$ & $1,346^{n s}$ & $1,167^{\mathrm{ns}}$ & $2,184^{*}$ & $0,844^{\text {ns }}$ & $0,982^{\mathrm{ns}}$ & $1,532^{\mathrm{ns}}$ & $1,599^{\text {ns }}$ \\
\hline
\end{tabular}

*,** - and ${ }^{\text {ns }}$ - Significant at $\mathrm{p} \leq 0.05, \mathrm{p} \leq 0.01$ and not significant according to the $\mathrm{F}$ test, respectively
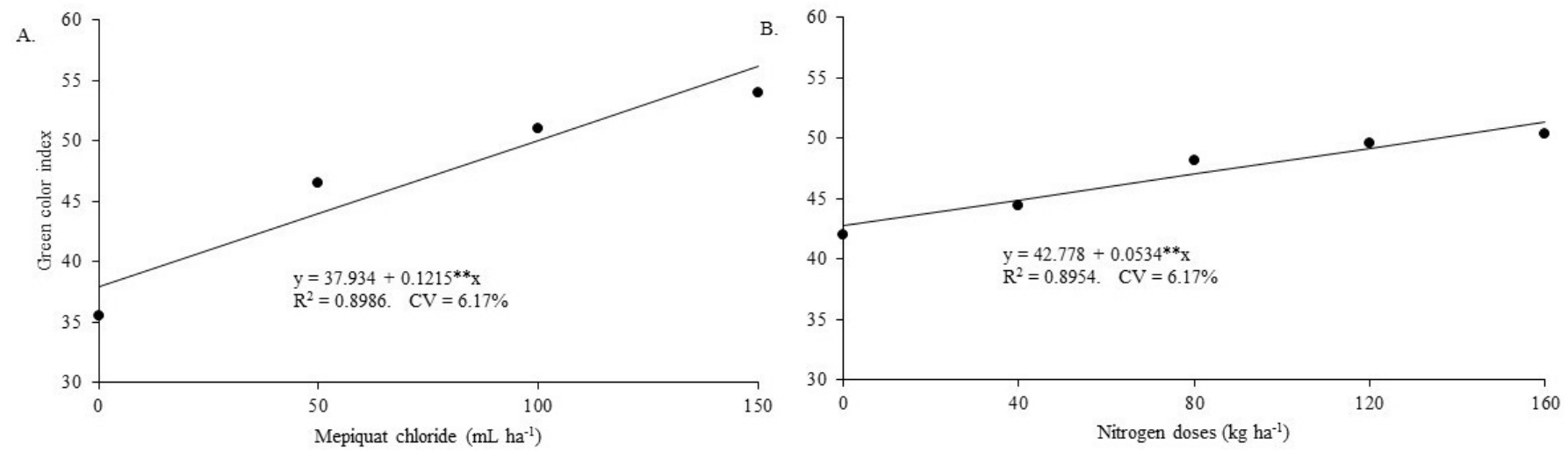

** Significant at $\mathrm{p} \leq 0.01$ according to the $\mathrm{F}$ test

Figure 2. (A) GCI (Green color index) as function of the mepiquat chloride doses; (B) GCI as function of the N doses, during the 2012/13 harvest 

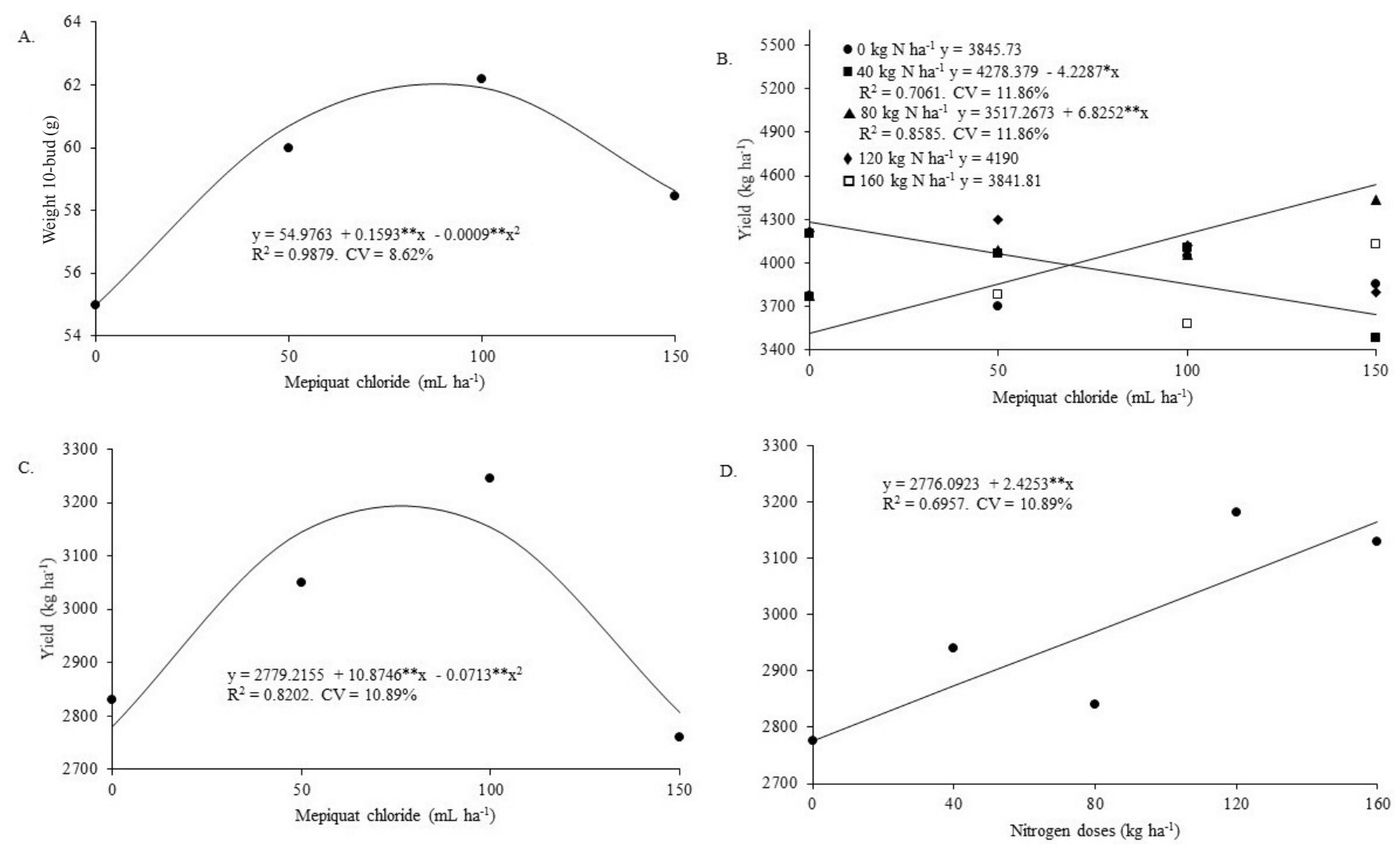

${ }^{*}$ and ${ }^{* *}$ Significant at $\mathrm{p} \leq 0.05$ and $\mathrm{p} \leq 0.01$ according to the $\mathrm{F}$ test, respectively

Figure 4. The weight 10-bud as function of the mepiquat chloride (MC) doses, 2013/14 crop (A); Yield as function of the MC doses with $\mathrm{N}$ application, 2012/13 crop (B); Yield as function of the MC doses, 2013/14 crop (C); Yield as function of the N doses, 2013/14 crop (D)

There were opposite responses to MC at doses of 40 and $80 \mathrm{~kg} \mathrm{ha}^{-1}$ with an $\mathrm{N}$ dose of $40 \mathrm{~kg} \mathrm{ha}^{-1}$. Productivity decreased as the MC dose increased. There was an increase in yield with the MC application with an $\mathrm{N}$ dose of $80 \mathrm{~kg} \mathrm{ha}^{-1}$ (Figure 4B).

The doses of $\mathrm{MC}$ and $\mathrm{N}$ individually altered the yield, which increased with $\mathrm{N}$ doses (Figure 4D). Regarding MC application, there was an increase in yield up to the dose of 77 $\mathrm{mL} \mathrm{ha}^{-1}$, with yield subsequently reduced by $13 \%$ for higher doses (Figure 4C).

The results obtained during 2012/13 showed that when 40 $\mathrm{kg}$ of $\mathrm{N} \mathrm{ha}^{-1}$ was applied, increasing the MC dose decreased productivity (Figure 4B). Therefore, the response to MC is dependent on the vegetative development of the crop. Approximately 70 days after sowing, cotton plants can absorb up to $3.6 \mathrm{~kg}$ of $\mathrm{N} \mathrm{ha}^{-1}$ per day, and under ideal conditions, the plants can absorb $250 \mathrm{~kg}$ of $\mathrm{N} \mathrm{ha}^{-1}$ during the cycle (Boquet \& Breitenbeck, 2000). A low supply of this nutrient could trigger a reduction in the vegetative potential of the crop without the necessity of the MC application.

However, the use of $80 \mathrm{~kg}$ of $\mathrm{N} \mathrm{ha}^{-1}$ increased the potential for vegetative growth. Larger-sized plants commonly presented an auto-shading index, mainly for the leaves in the middle and lower third, generating a lower photosynthetic rate (Echer \& Rosolem, 2015). With the MC application, the plants became more compact and had a greater ability to take advantage of the photosynthetically active wavelengths (Gu et al., 2014).

The increase in $\mathrm{N}$ doses caused an increase in productivity (Figure 4D). N scarcity in the cotton plants decreases the activity of approximately 67 enzymes, which are mainly related to the metabolism of carbohydrates and amino acids, modifying the cell wall and the formation of cytoskeletons. Thus, it indirectly affects cotton fiber production (Wang et al., 2012). This indicates that the supply of $\mathrm{N}$ to the crop leads to greater metabolic activity in the plant and greater photoassimilate production, which accounts for almost the entirety of cotton fiber production.

The MC increased yields up to the dose of $76.8 \mathrm{~mL} \mathrm{ha}^{-1}$ (Figure 4C), and higher doses were detrimental to the crop. This decline could be caused by the excessive reduction of GA levels in the plant. Such a reduction can reach $304 \%$ of $\mathrm{GA}_{3}$ and $43 \%$ of $\mathrm{GA}_{4}$ six days after MC application (Wang et al., 2014), and the excessive reduction of this hormone influences the physiological activity of the plant; thus, directly affecting productivity.

The lower rainfall during 2013/14 was a factor that reduced the need for MC application. The water stress in the crop along with the application of high MC doses causes a reduction in photosynthesis, the number of buds per plant, and dry mass (Rosolem et al., 2013). The effects caused by MC were reflected in the 10-bud mass during 2013/14, and this created a similar effect on yield (Figure 4A) because they are directly related factors.

There was a reduction in fiber maturity caused by increasing MC doses up to the dose of $100 \mathrm{~kg} \mathrm{~N} \mathrm{ha}^{-1}$ (Figure 5).

The reduced fiber maturity caused by the increase in $\mathrm{N}$ doses with a dose of $100 \mathrm{~mL}$ MC (Figure 5) occurred because MC acts directly on GA synthesis; thus, preventing fiber cell expansion and elongation (Shi et al., 2006), as well as 


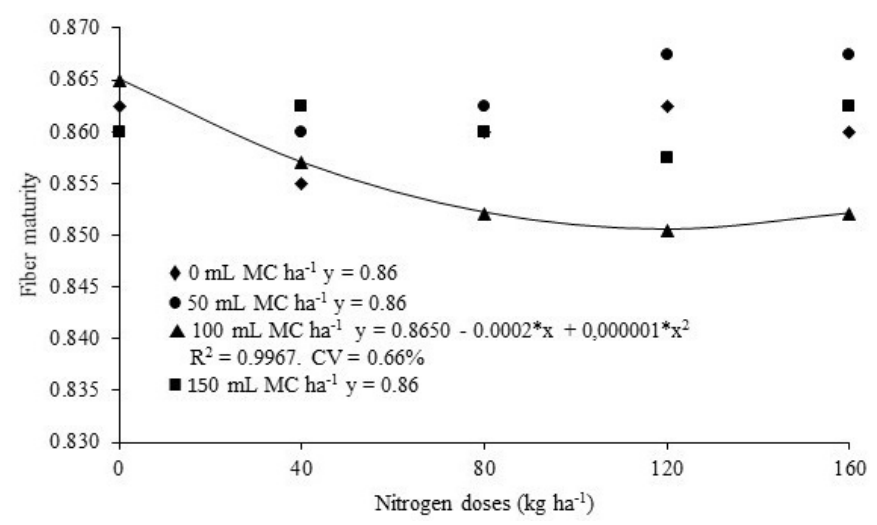

* Significant at $\mathrm{p} \leq 0.05$ according to the $\mathrm{F}$ test

Figure 5. Fiber maturity as function of mepiquat chloride (MC) doses and $\mathrm{N}$ applications during the 2012/13 harvest

affecting other factors connected to this reduction. Echer \& Rosolem (2015) observed that plants that received shading produced more mature fibers. The increase in MC doses causes a reduction in plant height, increasing the brightness in the plant canopy, and decreasing the maturity of fiber (Figure 5).

Low fiber maturity is one of the major problems encountered in the textile industry because these fibers tend to produce a weaker yarn that is likely to break during spinning. This increases the number of machine stops and producing a large number of "neps" in addition to decreasing the uniformity in the dyeing of fabrics (Long \& Bange, 2011). The international standard for the micronaire index ranges from 3.8 to $4.5 \mu \mathrm{g}$ $\mathrm{in}^{-2}$, values above this range create spinning problems because yarns have less resistance (Long \& Bange, 2011).
With significant interaction, the $\mathrm{N}$ dose of $120 \mathrm{~kg} \mathrm{ha}^{-1}$ provided a micronaire reduction with $\mathrm{MC}$ application (Figure 6). There was a reduction in micronaire when $100 \mathrm{~mL} \mathrm{ha}^{-1}$ of $\mathrm{MC}$ was used as the $\mathrm{N}$ doses increased. The $\mathrm{MC}$ and $\mathrm{N}$ dose individually influenced the uniformity of fibers, reducing uniformity.

The reduction in micronaire caused by nitrogen fertilization and $\mathrm{MC}$ leads to adaptation of the fiber to international standards (Figures 6A and B). However, MC application should be performed in a careful manner, because high doses may cause an increase in the micronaire because of the lower number of buds in the upper third in relation to the middle and lower third of plants.

Zancan et al. (2013) observed that the buds produced in the branches of the middle and lower third tended to produce fibers with higher micronaire. The reduced micronaire caused by the increasing $\mathrm{N}$ dose was not only linked to plant physiology but also to changes in its morphology. Based on the increase in $\mathrm{N}$ supply, the plants tended to present greater vegetative growth; consequently, a higher number of rotten apples occurred in the middle and lower third, increasing the proportion of buds in the upper third part of the plant.

The uniformity of the fibers also exhibited a reduction when the MC and $\mathrm{N}$ doses were increased. In a study with 50 cotton cultivars, Pan et al. (2010) observed that the fiber uniformity presented a direct correlation with the cellulose content in the fiber and the micronaire, indicating the similar behavior of the variables analyzed in this study.

According to the obtained results, the higher the dose of $\mathrm{N}$ and $\mathrm{MC}$, the lower the distribution uniformity of the
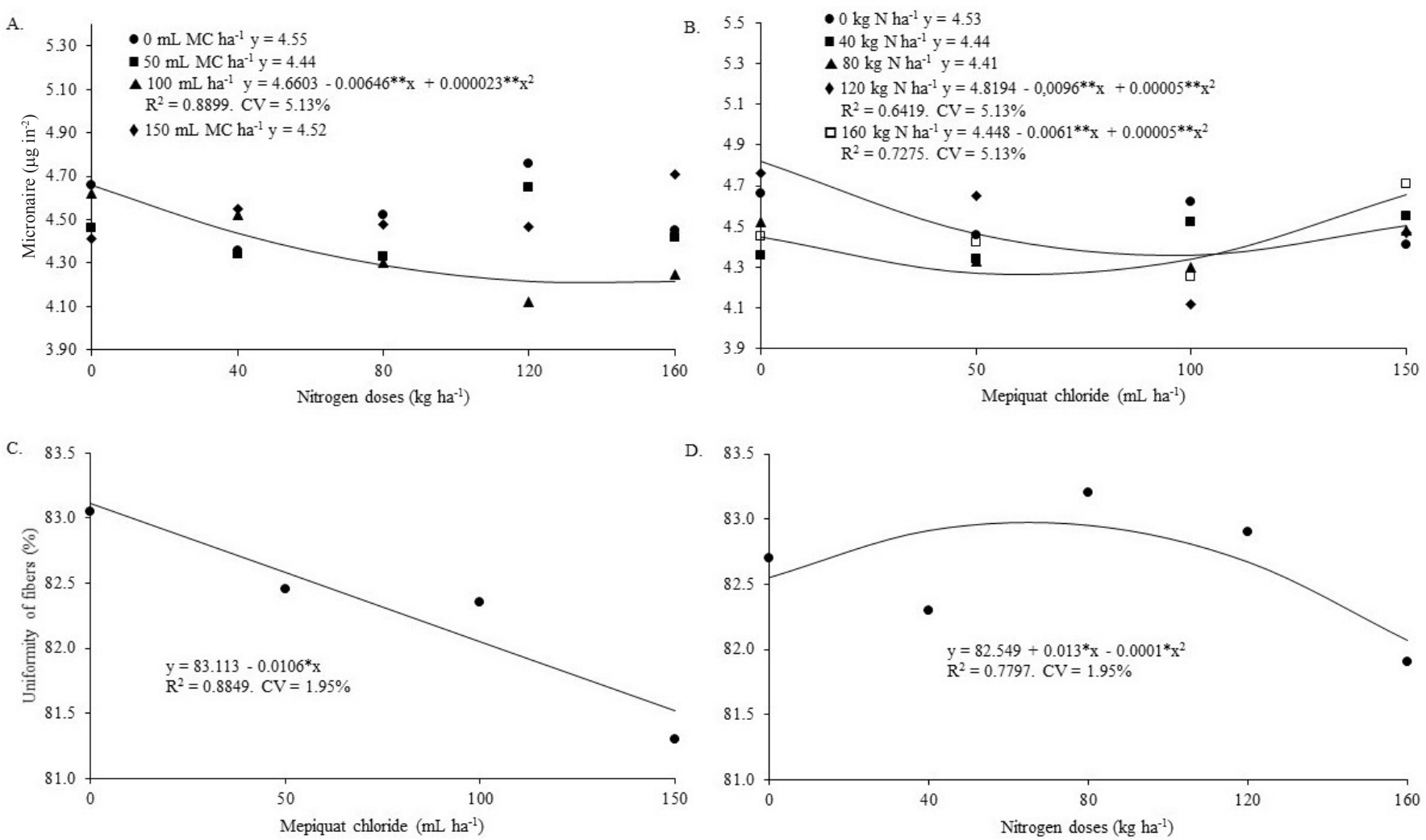

${ }^{*}$ and ${ }^{* *}$ Significant at $\mathrm{p} \leq 0.05$ and $\mathrm{p} \leq 0.01$ according to the $\mathrm{F}$ test, respectively

Figure 6. Micronaire as function of the $\mathrm{N}$ doses within the mepiquat chloride (MC) doses (A); Micronaire as function of the MC doses within the $\mathrm{N}$ doses (B); Fiber uniformity as function of MC doses (C); Fiber uniformity as function of the $\mathrm{N}$ doses (D), during the 2012/13 harvest 
fiber length (Figures 6C and D), to the point of reducing the uniformity category according to the classification by the USDA (2018) from high to medium with an $\mathrm{N}$ dose of $160 \mathrm{~kg} \mathrm{ha}^{-1}$, but there was a gain in productivity.

\section{Conclusions}

1. The best results for fiber quality and yield occurred with the application of $76.8 \mathrm{~mL} \mathrm{ha}^{-1}$ of mepiquat chloride to the cotton crop when the $\mathrm{N}$ dose was greater than $80 \mathrm{~kg} \mathrm{ha}^{-1}$.

2. Increasing $\mathrm{N}$ doses promoted an increase in cotton yield and micronaire index, but there was a decrease in fiber uniformity.

\section{Literature Cited}

Boquet, D. J.; Breitenbeck, G. A. Nitrogen rate effect on partitioning of nitrogen and dry matter by cotton. Crop Science, v.40, p.16851693, 2000. https://doi.org/10.2135/cropsci2000.4061685x

CONAB - Companhia Nacional de Abastecimento. Acompanhamento da safra brasileira de grãos. Safra 2017/18 - Sétimo levantamento. Brasília: CONAB, 2018. 139p.

Cunha, F. F.; Magalhães, F. F.; Castro, M. A. Métodos para estimativa da evapotranspiração de referência para Chapadão do Sul - MS. Engenharia na Agricultura, v.21, p.159-172, 2013. https://doi. org/10.13083/1414-3984.v21n02a06

Ducamp, F.; Arriaga, F. J.; Balkcom, K. S.; Prior, S. A.; Santen, E. van; Mitchell, C. C. Cover crop biomass harvest influences cotton nitrogen utilization and productivity. International Journal of Agronomy, v.2012, p.1-12, 2012. https://doi. org/10.1155/2012/420624

Echer, F. R.; Rosolem, C. A. Cotton leaf gas exchange responses to irradiance and leaf aging. Biologia Plantarum, v.59, p.366-372, 2015. https://doi.org/10.1007/s10535-015-0484-3

Gonias, E. D.; Oosterhuis, D. M.; Bibi, A. C. Cotton radiation use efficiency response to plant growth regulators. The Journal of Agricultural Science, v.150, p.595-602, 2012. https://doi. org/10.1017/S0021859611000803

Gu, S.; Evers, J. B.; Zhang, L.; Mao, L.; Zhang, S.; Zhao, X.; Liu, S.; Werf, $\mathrm{W}$. van der; Li, Z. Modelling the structural response of cotton plants to mepiquat chloride and population density. Annals of Botany, v.114, p.877-887, 2014. https://doi.org/10.1093/aob/mct309

Long, R. L.; Bange, M. P. Field crops research consequences of immature fiber on the processing performance of upland cotton. Field Crops Research, v.121, p.401-407, 2011. https://doi. org/10.1016/j.fcr.2011.01.008

Ma, R. H.; Xu, N. Y.; Zhang, C. X.; Li, W. F.; Feng, Y.; Qu, L.; Wang, Y. H.; Zhou, Z. G. Physiological mechanism of sucrose metabolism in cotton fiber and fiber strength regulated by nitrogen. Acta Agronomica Sinica, v.34, p.2143-2151, 2008. https://doi. org/10.1016/S1875-2780(09)60023-7
Pan, Z.; Sun, D.; Sun, J.; Zhou, Z.; Jia, Y.; Pang, B.; Ma, Z.; Du, X. Effects of fiber wax and cellulose content on colored cotton fiber quality. Euphytica, v.173, p.141-149, 2010. https://doi.org/10.1007/ s10681-010-0124-0

Ren, X.; Zhang, L.; Du, M.; Evers, J. B.; Werf, W. van der; Tian, X.; $\mathrm{Li}, \mathrm{Z}$. Managing mepiquat chloride and plant density for optimal yield and quality of cotton. Field Crops Research, v.149, p.1-10, 2013. https://doi.org/10.1016/j.fcr.2013.04.014

Rosolem, C. A.; Oosterhuis, D. M.; Souza, F. S. de. Cotton response to mepiquat chloride and temperature. Scientia Agricola, v.70, p.82-87, 2013. https://doi.org/10.1590/S0103-90162013000200004

Sestren, J. A.; Lima, J. J. Característica e classificação da fibra de algodão. In: Algodão no cerrado do Brasil. Brasília: Associação Brasileira dos Produtores de Algodão, 2007. Cap.22, p.765-820.

Shi, Y. H.; Zhu, S. W.; Mao, X. Z.; Feng, J. X.; Qin, Y. M.; Zhang, L.; Cheng, J.; Wei, L. P.; Wang, Z. Y.; Zhu, Y. X. Transcriptome profiling, molecular biological, and physiological studies reveal a major role for ethylene in cotton fiber cell elongation. The Plant Cell, v.18, p.651-664, 2006. https://doi.org/10.1105/ tpc.105.040303

Silva, C. A. D.; Almeida, R. P. Manejo integrado de pragas do algodoeiro no Brasil. Campina Grande: Embrapa Algodão, 1998. 65p. Circular Técnica, 27

USDA - United States Department of Agriculture. Cotton exporters guide: Use instrument cotton classification. Available on: <http:// www.cottonguide.org/cotton-guide/cotton-value-addition-useof-instrumentation-in-cotton-classification>. Accessed on: Ago. 2018.

Wang, L.; Mu, C.; Du, M.; Chen, Y.; Tian, X.; Zhang, M.; Li, Z. The effect of mepiquat chloride on elongation of cotton (Gossypium hirsutum L.) internode is associated with low concentration of gibberellic acid. Plant Science, v.225, p.15-23, 2014. https://doi. org/10.1016/j.plantsci.2014.05.005

Wang, Y. H.; Zheng, M.; Gao, X. B.; Zhou, Z. G. Protein differential expression in the elongating cotton (Gossypium hirsutum L.) fiber under nitrogen stress. Science China Life Sciences, v.55, p.984992, 2012. https://doi.org/10.1007/s11427-012-4390-z

Wiedenfeld, B.; Wallace, B. W.; Hons, F. Indicators of cotton nitrogen status. Journal of Plant Nutrition, v.32, p.1353-1370, 2009. https:// doi.org/10.1080/01904160903006044

Zancan, W. L. A.; Chitarra, L. G.; Chitarra, G. S. Cotton in Brazil: Importance and chemical control of bolls rot. In: Nita, M. (ed.). Fungicides-showcases of integrated plant disease management from around the world. London: IntechOpen Limited, 2013. Cap.7. p.135-152.

Zhou, G.; Yin, X. Relationship of cotton nitrogen and yield with normalized difference vegetation index and plant height. Nutrient Cycling in Agroecosystems, v.100, p.147-160, 2014. https://doi. org/10.1007/s10705-014-9640-y 